\title{
Enhanced interior gateway routing protocol (EIGRP) website based on cisco router 2811 using application programming interface (API) from cisco
}

\author{
Sudaryanto Sudaryanto ${ }^{1}$, Anggraini Kusumaningrum ${ }^{2, *}$, Yuliani Indrianingsih", , Dadan Rachman \\ Prabowo $^{4}$ \\ 1,2,3 Informatic Study Program, Adisutjipto Institut of Aerospace Technology, Indonesia \\ ${ }^{4}$ Informatic Study Program, Adisutjipto College of Technology, Indonesia
}

\begin{tabular}{|c|c|}
\hline Article Info & ABSTRAK \\
\hline Article history: & Enhanced Interior Gateway Routing Protocol (EIGRP) is a routing protocol \\
\hline Received May 27, 2021 & that can be used to determine the path of data to be sent. EIGRP can achieve \\
\hline Accepted October 19,2021 & to determine the best path. EIGRP is only adopted by Cisco routers or can be \\
\hline Published November 30, 2021 & called a Cisco Proprietary Protocol, which can only be used on Cisco router \\
\hline Kata Kunci: & $\begin{array}{l}\text { devices. Currently, the EIGRP routing configuration uses the command line. } \\
\text { For this reason, a website-based EIGRP system was created and can be } \\
\text { accessed remotely with the aim of providing freedom of access and not }\end{array}$ \\
\hline EIGRP & focusing on one device. Website-based EIGRP system was created by utilizing \\
\hline API Cisco & Cisco's API as a liaison between the programming language and Cisco Router \\
\hline Telnet & 2811 software. Telnet utilization plays an important role in creating a website- \\
\hline Cisco Router 2811 & $\begin{array}{l}\text { based EIGRP system where Telnet can provide wider access in management. } \\
\text { By visiting the host and port of the router, the EIGRP Website Based System } \\
\text { can easily do the program. The results of the test in this study indicate that the } \\
\text { Website-based EIGRP system is proven to be able to configure, so that } \\
\text { administrators can use it for device management of Cisco Router } 2811 \text {. }\end{array}$ \\
\hline
\end{tabular}

\section{Corresponding Author:}

Anggra ini Kusumaningrum, Informatics Study Program, Adisutjipto Institut of Aerospace Technology, block R Adisutjipto Airbase Yogyakarta 55198, Indonesia. Email: *anggraini@itda.ac.id

\section{INTRODUCTION}

One part of the computer networks that is needed to exchange data is a routing protocol [1]. The routing protocol will determine the data path on the router that is sent to reach its destination and leam the interconnected networks in order to obtain information. Enhanced Interior Gateway Routing Protocol (EIGRP) is a routing protocol that can be used to overcome this problem. EIGRP uses the Diffusing Update Algorithm (DUAL) to determine the best path. DUAL has functions to perform calculations and build routing tables a s well as to a scertain network paths and provide a loopless routing environment in order to a ssist in sending packets [2]. Damaged or corrupted packets can cause incorrect information on the router so that information route can be lost and the loopless routing will occur. In a ddition, somtimes the router will send the packetback so that the router will get the correct information and the route will return to normal.

In a study entitled [3] conducted an EIGRP routing performance analysis to determine the best path and ability to transmit data, EIGRP has a system of routing protocols that is used to calculate and construct a routing table and to ensure network paths that provides a loopless routing environment to help in delivering a packet across the network. Loopless routing can occur when updating information about the loss of a route; since it cannot be accepted by all routers on thenetwork. Thus the router that receives the update will assume that there is a problem with the network. When the origin router (sender) does not receive a packet from a neighbor within a certain period of time, the origin router (sender) will send a ga in the update 
packet. The result of these parameters is the EIGRP protocol has the ability to transmit data of $1.14 \mathrm{Mbps}$ with a delay (response time) of $1 \mathrm{~s}$.

In a study entitled [4] dynamic routing is a process that has and creates routing tables automatically by listening to network traffic and also by connecting to other routers. In simulation research using the EIGRP protocol with IPv4 implementation in star and ring topologies, the parameters to be tested are throughput and delay. In addition, this research also provides network a uthentication with a radius server using zeroshell. From the test results, the throughput and delay values are in a good category that have met the ITU-T standard and zeroshell can run well with the EIGRP protocol.

In previous studies, no one has conducted research for EIGRP routing management and monitoring, so this resea rch has a goal at administrators, and can be used for: creating a website-based user interface management and monitoring EIGRP routing protocol.

\section{RESEARCHMETHOD}

EIGRP is a protocol that is included in the Interior Ga teway Protocol, but it uses an Autonomous System. On a large internet network, the network will be divided into small networks called autonomous systems, each autonomous system manages its own area, then the router inside an autonomous system is called the Interior Gateway Protocol (IGP). Cisco introduced EIGRP in a nother term called the Balanced Hybrid Routing Protocol because the EIGRP protocol uses the features of the distance vector protocol and link-state protocol. EIGRP uses bandwidth and delay-based formulas that are useful for calculating metrics that match the routes traversed. This formula is a lmost the same as that is used by IGRP but the number is multiplied by 256 which is to accommodate calculations when the value of the bandwidth used is high. EIGRP converges rapidly to a void loops. The convergence of EIGRP is fa ster than the distance vector protocol, it is because EIGRP doesnot require loop av oidance which causes the convergence of the distance vector protocol to be slow.

Cisco Router 2811 is one of the routers manufactured by Cisco. Currently the EIGRP routing protocol configuration is still based on the Command Line Interface (CLI), so it must require network administrators to fully understand the routing protocol configuration commands. Of course, it is not easy and less effective. Therefore, we need a software based on a Graphical User Interface (GUI) that can configure EIGRP.

\subsection{DATA COLLECTIONMETHOD}

The methodology used for data collection in the study is as follows:

a. Observation In this method, direct observations were made to the object of research in the la boratory of an agency regarding matters rela ted to theEIGRP routing management protocol.

b. Interview

The interview was conducted by collecting data through direct interview with la boratory administrators (network administrators) and interview with lecturers who a recompetent in theirfields.

c. Study of literature

In this method, it aims to collect relevant theories in the problem being researched by rea ding books and journals rela ted to the problem.

\subsection{SYSTEMDESIGN}

The Web-based EIGRP on the Cisco Router 2811 that will be built requires design in advance through several stages of the Unified Modeling Language (UML) which consists of use case diagrams and activity diagrams.

a. Use Ca se Diagram

Use Case Diagrams are used to briefly describe who can use the system and what can be done on the system. 


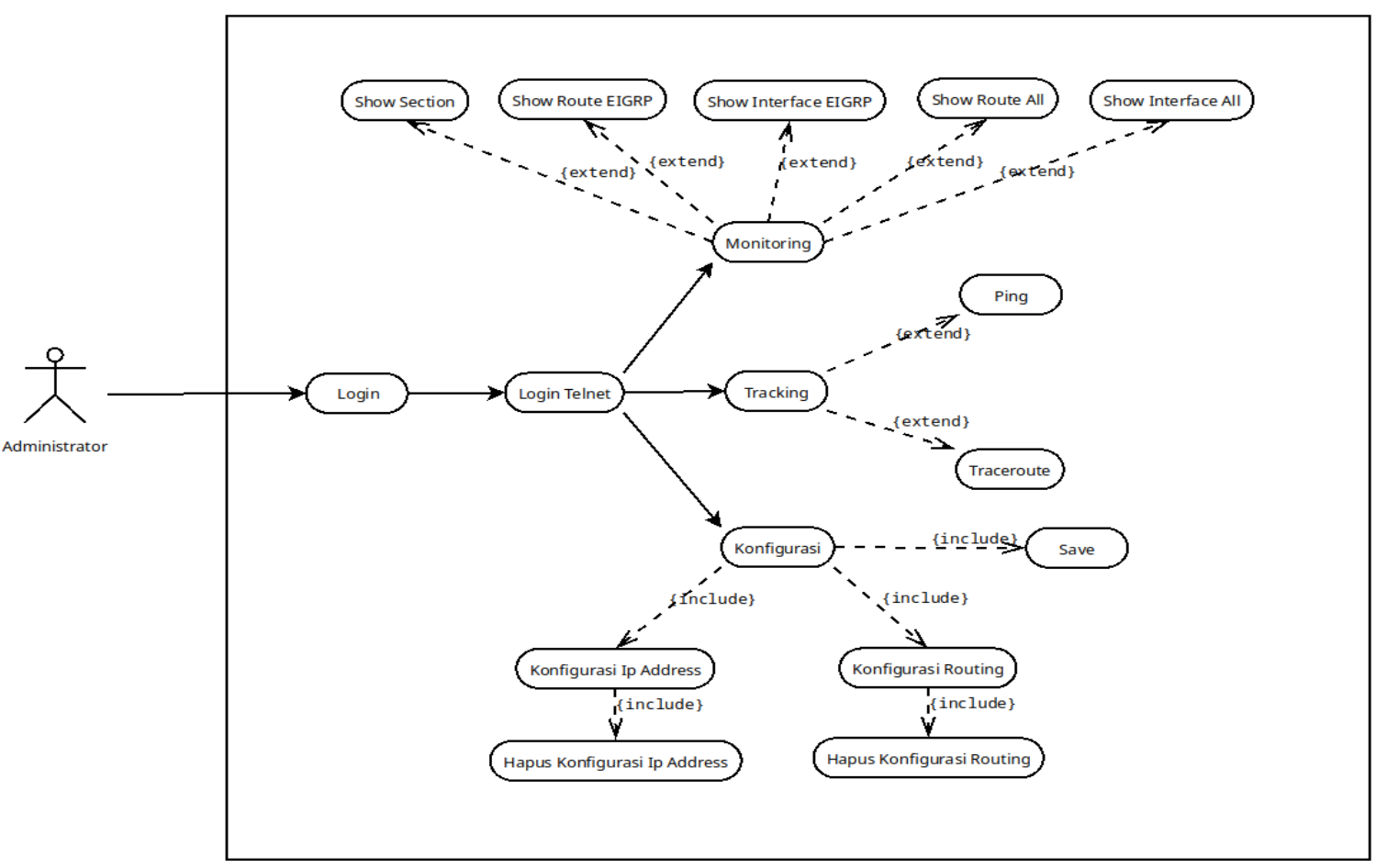

Figure 1 EIGRP Web-based Use Case Dia gram

b. Activity Diagra millustra tes a series of flow in any activities that can be performed by system users or a dministrators.

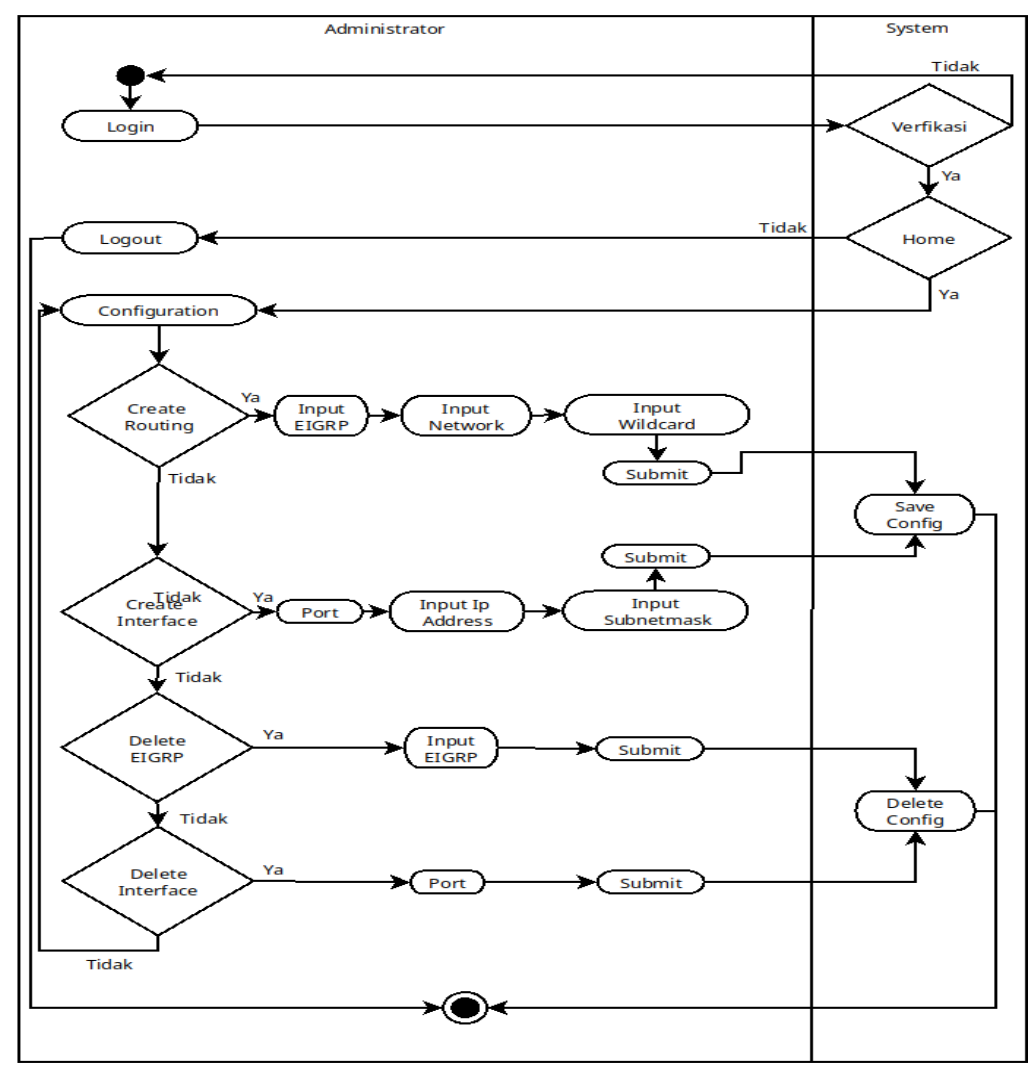

Figure 2 EIGRP Web-Based System Configuration Activity Dia gram 


\section{RESULT AND DISCUSSION}

Testing was done by means of a ping test on each computer to find out the reply of each condition. The test was carried out at the Adisutjipto Institute of Aerospace Technology Network Laboratory and used a Bus topology.

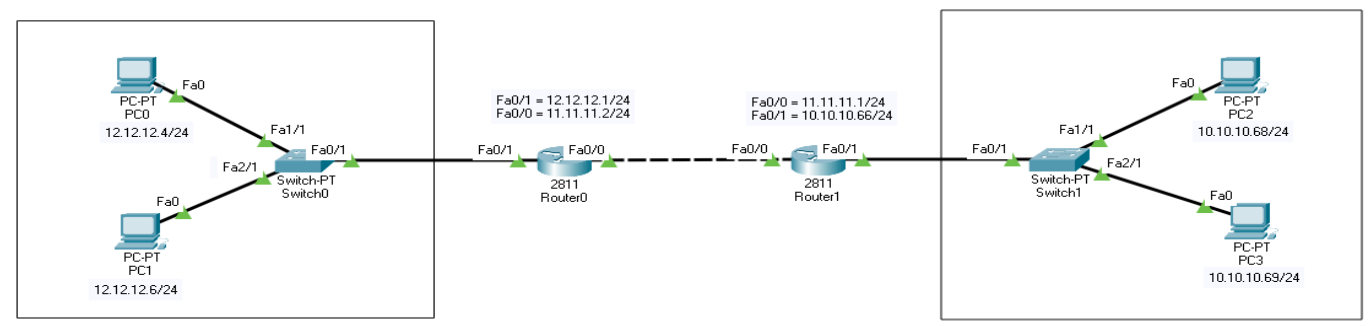

Figure 3 Network Testing Topology

\subsection{COMPUTER RELATIONSHIP WITHOUT EIGRPROUTING}

In this test, all computers were not using EIGRP routing or before it was configured. The testing process was done by pinging the computer's IP address. Ping test wa s done using 4 computers and 2 routers.

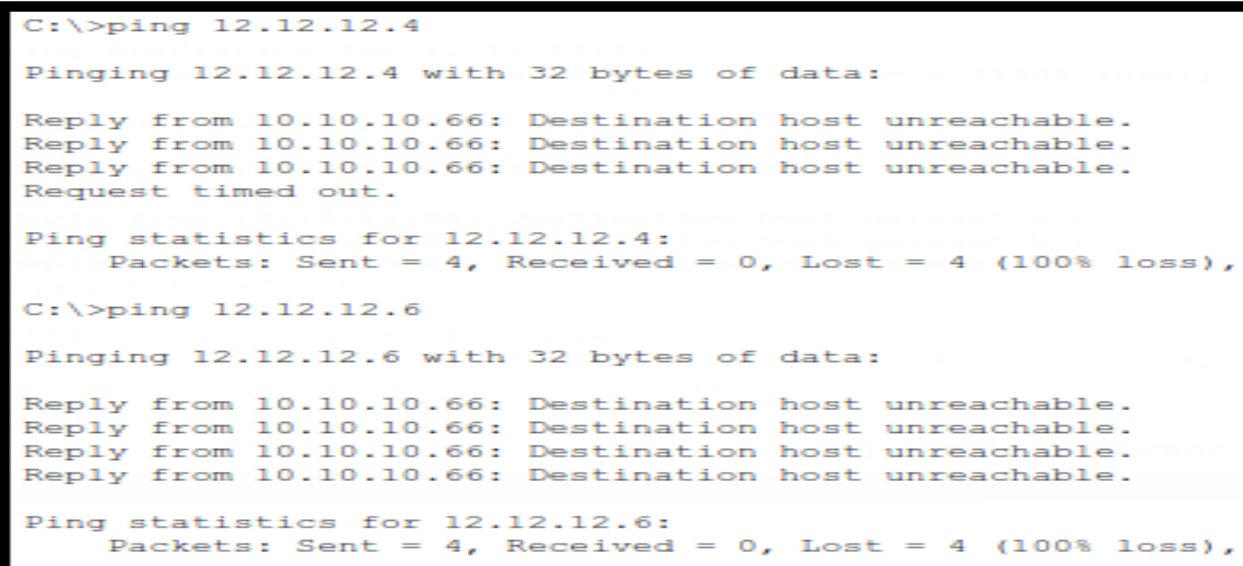

Figure 4 PC1 Ping Test without EIGRPRouting Configuration on IP 12.12.12.4 and 12.12.12.6

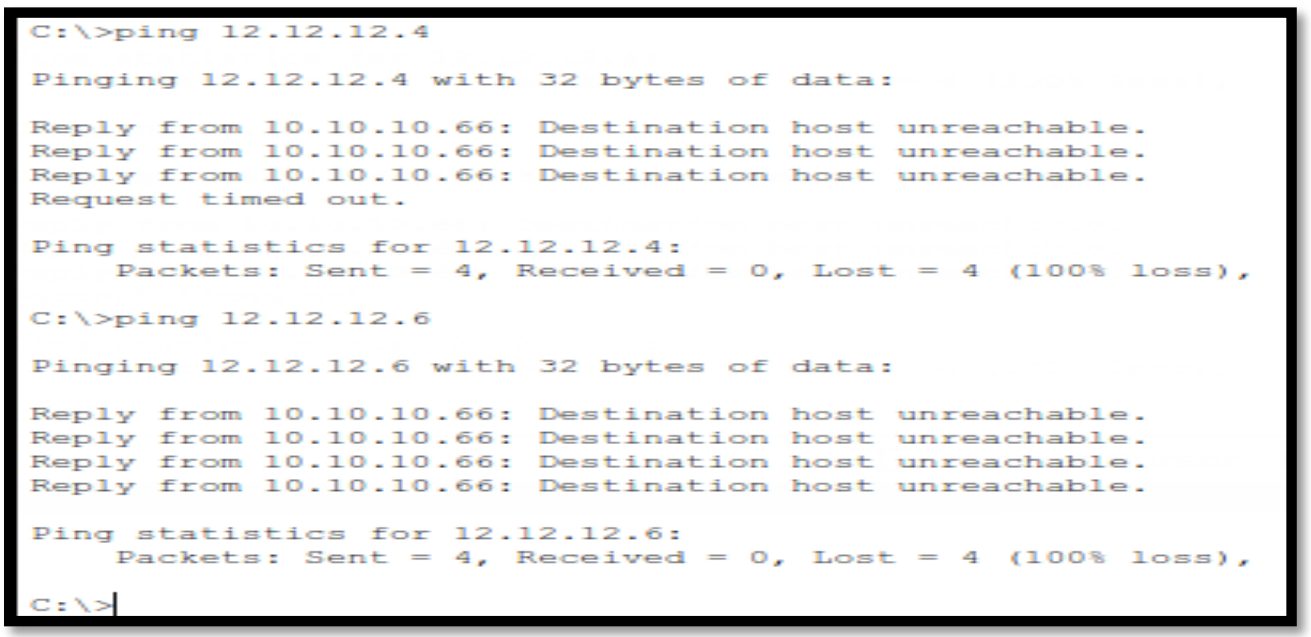

Figure 5 PC2 Ping Test without EIGRP Routing Configuration on IP 12.12.12.4 and 12.12.12.6 


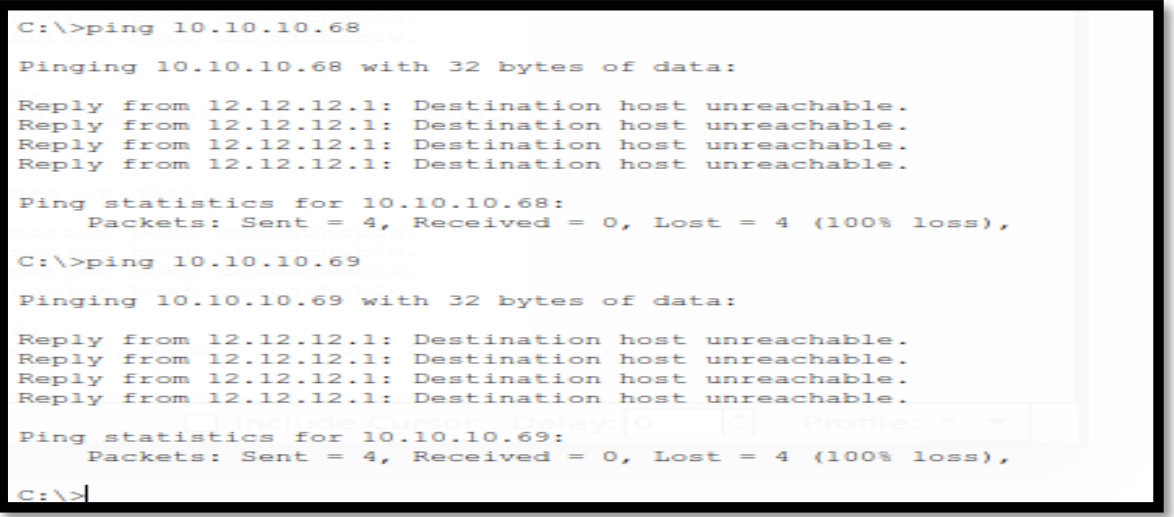

Figure 6 PC3 Ping Test without EIGRP Routing Configuration on IP 10.10.10.68 and 10.10.10.69

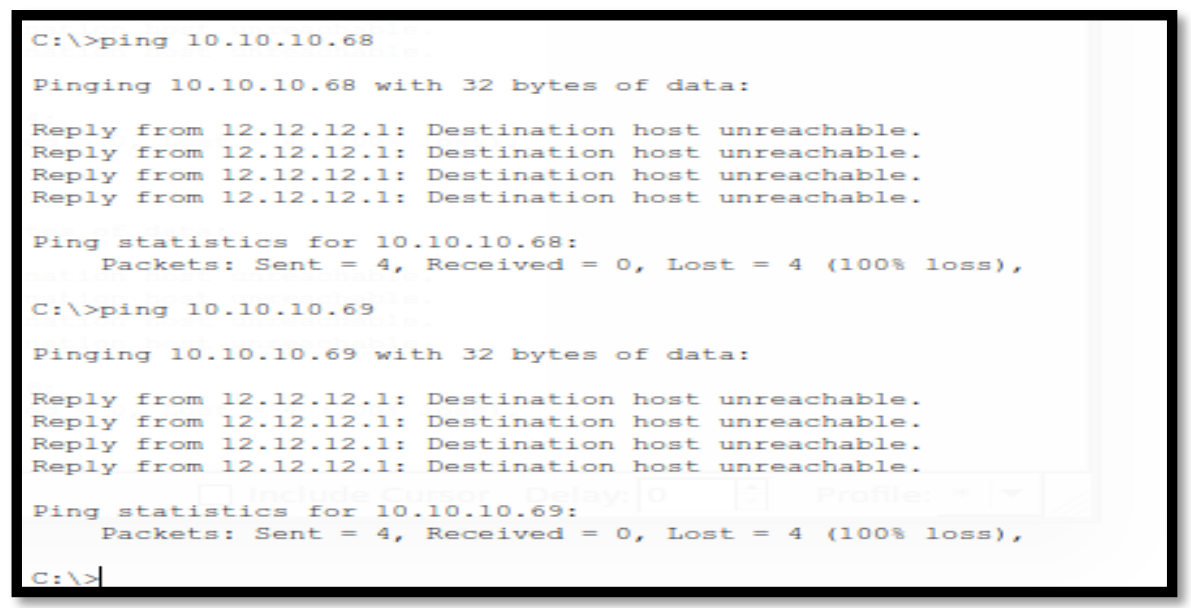

Figure 7 PC4 Ping Test without EIGRP Routing Configuration on IP 10.10.10.68 and 10.10.10.69

From Figure 4 to 7 , they show an image that performs a ping test using the command line on windows, which means that PC1 until PC4 a re not connected.

Table 1 Computer Connection Without EIGRP Routing

\begin{tabular}{|l|l|l|l|}
\hline & \multicolumn{1}{|c|}{ IPCOMPUTER } & \multicolumn{1}{|c|}{ DESTINATION } & \multicolumn{1}{|c|}{ RESULT } \\
\hline PC 1 & 10.10 .10 .68 & 12.12 .12 .4 & NOT CONNECTED \\
\hline PC 2 & 10.10 .10 .69 & 12.12 .12 .6 & NOT CONNECTED \\
\hline PC 3 & 12.12 .12 .4 & 10.10 .10 .68 & NOT CONNECTED \\
\hline PC 4 & 12.12 .12 .6 & 10.10 .10 .69 & NOT CONNECTED \\
\hline
\end{tabular}

\subsection{COMPUTER RELATIONSHIP WITH EIGRP ROUTING}

At this stage, EIGRP routing was created or configured on a Cisco 2811 Router device. The testing process wa sa rried out by pinging the computer's IP a ddress. Ping test was done using 4 computers and 2 routers. 


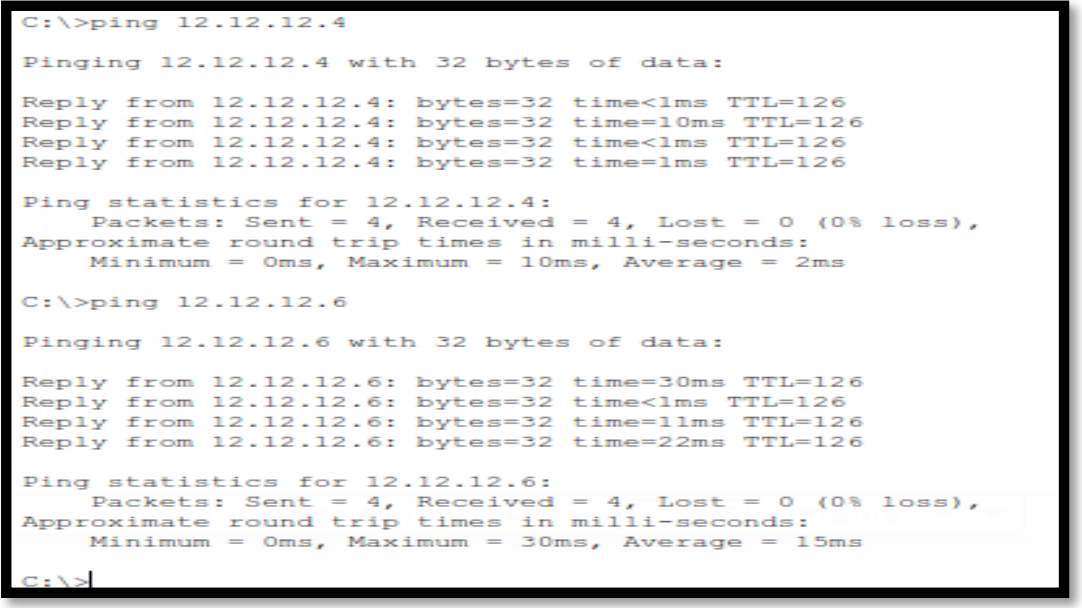

Figure 8 PC1 Ping Test with EIGRP Routing Configuration on IP 12.12.12.4 and 12.12.12.6

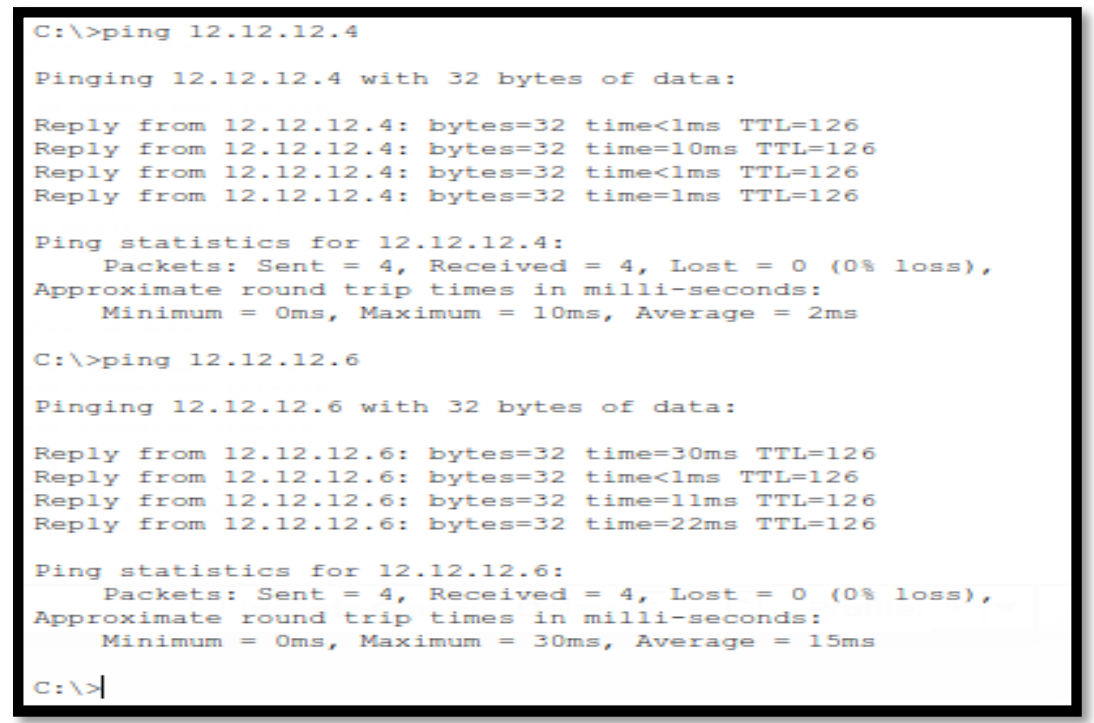

Figure 9 PC2 Ping Test with EIGRP Routing Configuration on IP 12.12.12.4 and 12.12.12.6

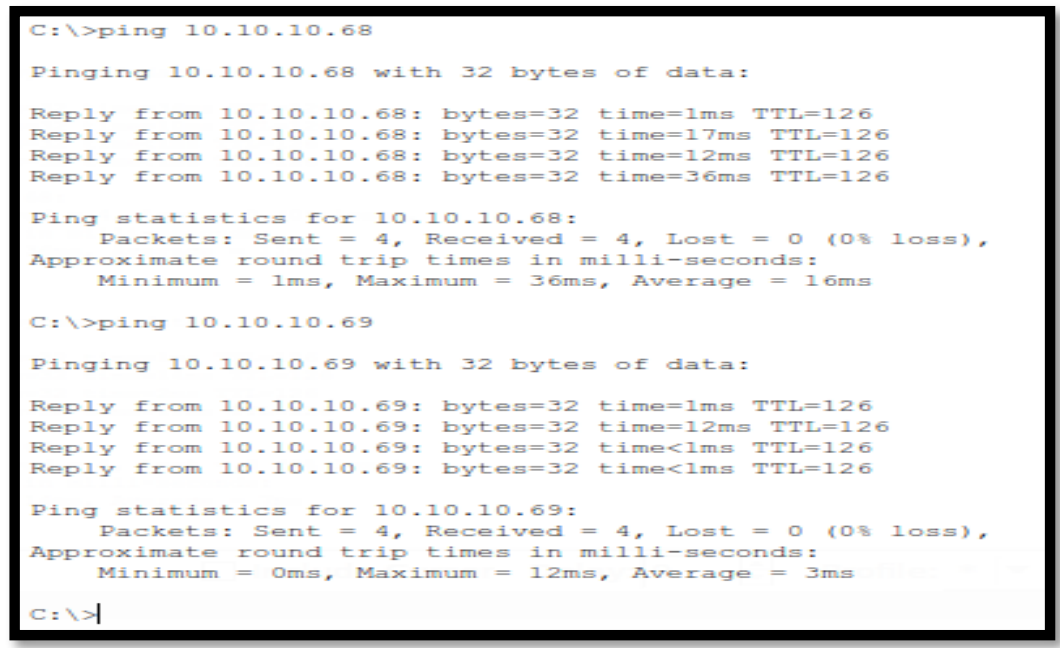

Figure 10 PC3 Ping Test with EIGRP Routing Configuration on IP 10.10.10.68 and 10.10.10.69 


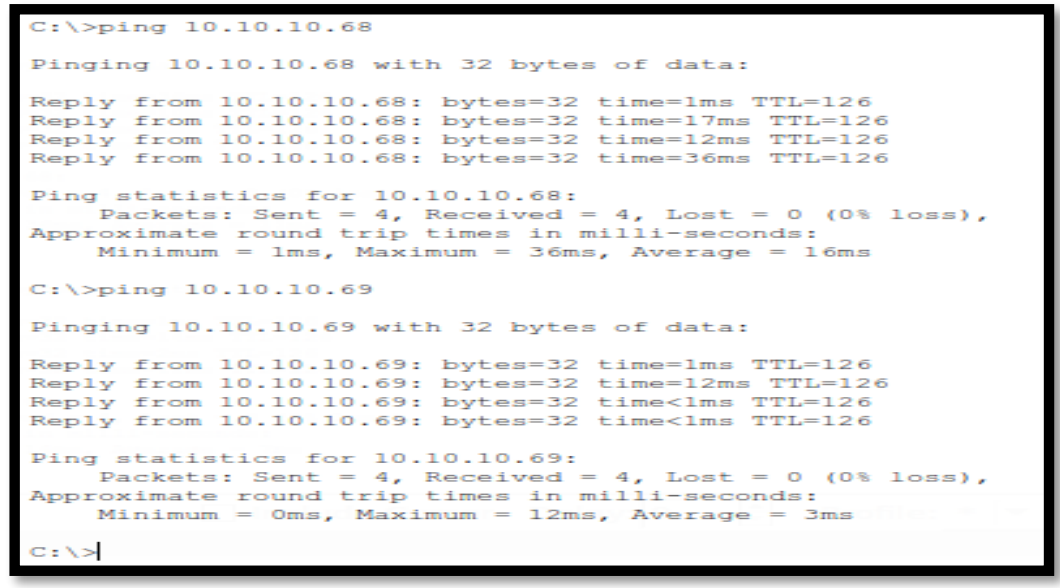

Figure 11 PC4 Ping Test with EIGRP Routing Configuration on IP 10.10.10.68 and 10.10.10.69

From Figure 8 to 11 , they show an image that performs a ping test using the command line on windows which means that PC1 until PC4 can be connected.

Table 2 Computer Connection Using EIGRP

\begin{tabular}{llll}
\hline & \multicolumn{1}{c}{ IP COMPUTER } & \multicolumn{1}{c}{ DESTINATION } & RESULT \\
\hline PC 1 & 10.10 .10 .68 & 12.12 .12 .4 & CONNECTED \\
\hline PC 2 & 10.10 .10 .69 & 12.12 .12 .6 & CONNECTED \\
\hline PC 3 & 12.12 .12 .4 & 10.10 .10 .68 & CONNECTED \\
\hline PC 4 & 12.12 .12 .6 & 10.10 .10 .69 & CONNECTED \\
\hline
\end{tabular}

\subsection{TESTING USING TRACEROUTE}

At this stage, testing was carried out using a traceroute to find out which paths the computer tra verses. Traceroute was done with computer 1 to computer 4 and vice versa.

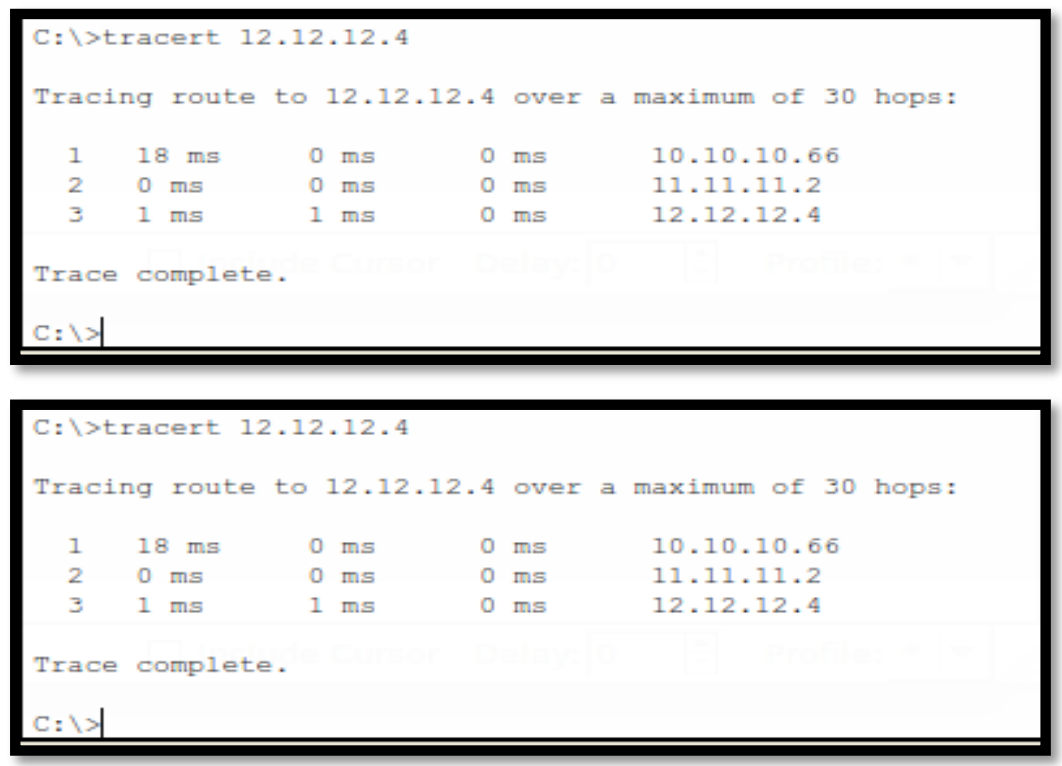

Figure 12 Traceroute PC1 With EIGRP Routing Configuration on IP 12.12.12.4 


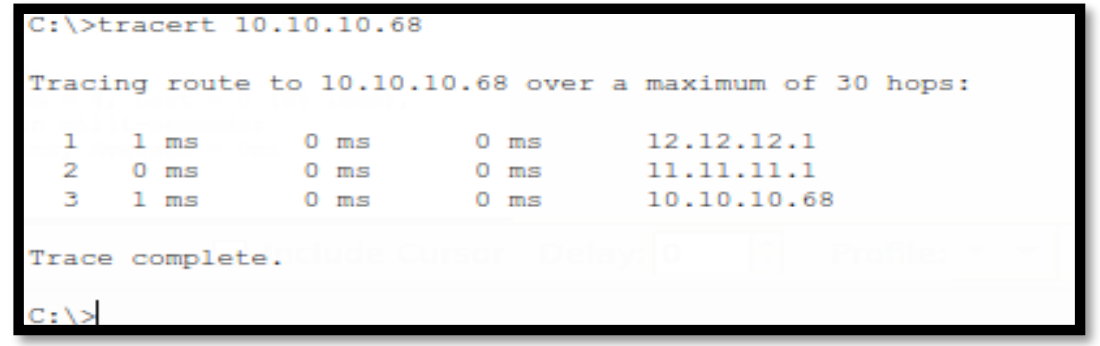

Figure 13 Traceroute PC2 With EIGRP Routing Configuration on IP 10.10.10.68

Figure 12 and Figure 13 show the path that is passed by the connected PC after EIGRP routing, the result is that PC 1 and PC 2 pass through the route or router that has been configured with EIGRP routing. And the following routing table that has been configured on the router is shown in Figure 14 and Figure 15.

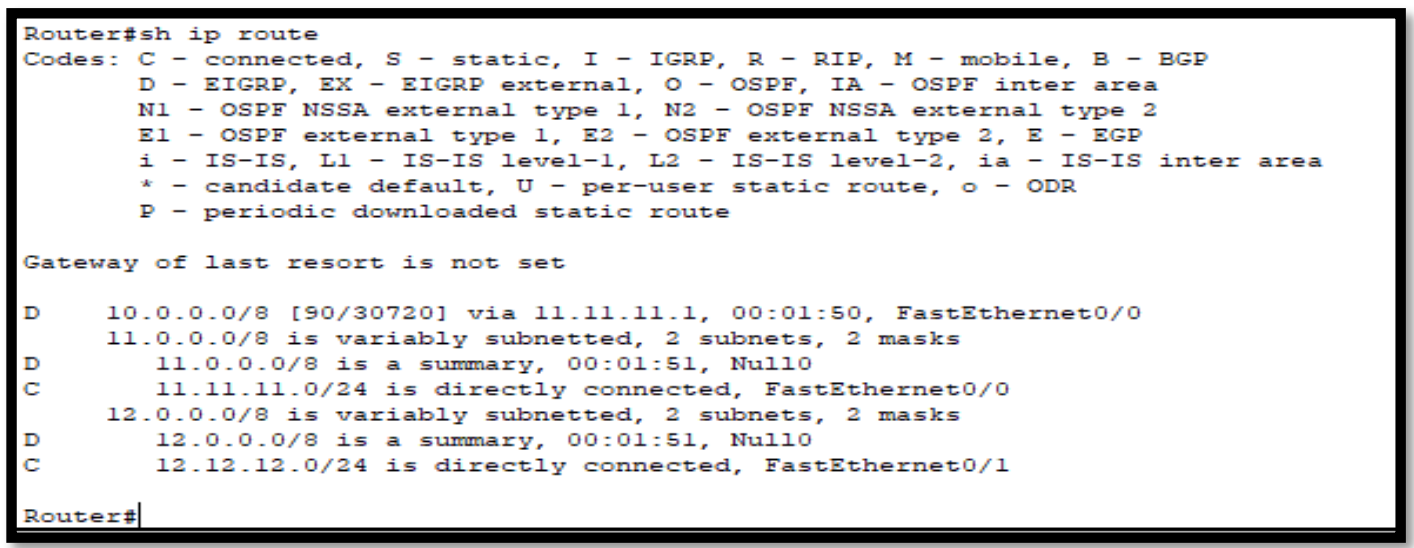

Figure 14 Table Routing Router 1

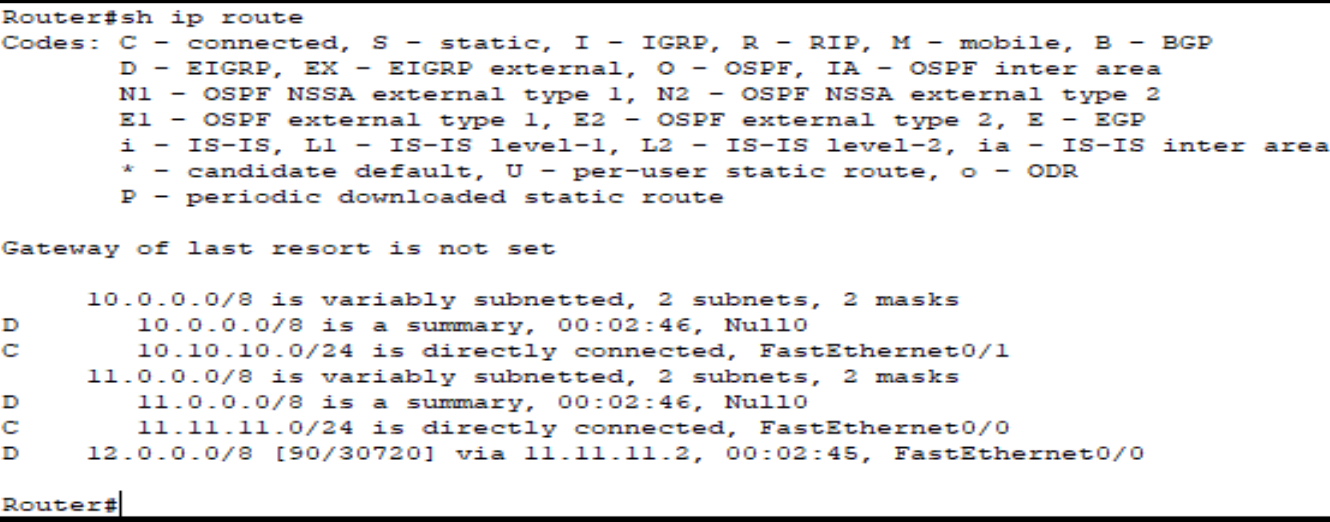

Figure 15 Table Routing Router 2

\subsection{TESTING THE PROCESS USING THE GUI AND CLI}

In this part of the test, the process was carried out using the GUI and CLI. This test showed the results in the form of time which can conclude the effectiveness of the time to configure EIGRP routing on Cisco Router 2811 devices.

Table 3 Testing Process Using GUI and CLI

\begin{tabular}{llll}
\hline \multicolumn{1}{c}{ PROCESS } & GUI & CLI & DIFFERENCE \\
\hline Add Ip Address & 1,26 seconds & 0,44 seconds & 0,82 seconds \\
\hline
\end{tabular}




\begin{tabular}{llll}
\hline Routing Eigrp & 1,20 seconds & 7,84 seconds & 6,64 seconds \\
\hline Show Section & 31,55 seconds & 1,20 seconds & 30,35 seconds \\
\hline Show Route Eigrp & 1,03 seconds & 0,34 seconds & 0,69 seconds \\
\hline Show Interfaces Eigrp & 0,87 seconds & 0,36 seconds & 0,59 seconds \\
\hline Show Route All & 0,90 seconds & 0,31 seconds & 0,41 seconds \\
\hline Show Interfaces All & 0.72 seconds & 0,31 seconds & 0,09 seconds \\
\hline Tracking Ping & 0,43 seconds & 0,34 seconds & 0,88 seconds \\
\hline Tracking Traceroute & 21,78 seconds & 20,90 seconds & 1,34 seconds \\
\hline Delete Routing & 1,00 seconds & 2,34 seconds & 0,29 seconds \\
\hline Delete Interfaces & 0,88 seconds & 0,59 seconds & 32,04 seconds \\
\hline Save & 32,76 seconds & 0,72 seconds & $\mathbf{4 , 9}$ seconds \\
\hline Average & $\mathbf{7 , 9}$ seconds & $\mathbf{3}$ seconds & \\
\hline
\end{tabular}

Table 3 shows that the best a verage result is on the CLI with a time of 3 seconds, because the CLI does not show output colors and web design shapes. Therefore, the CLI is faster but it only shows the outputs of text.

\subsection{RESEARCHDEVELOPMENT}

This resea rch was conducted by developing the results of previous studies which was the research in the field of computer networks a bout network security using devices from Cisco. Where in configuring and monitoring Cisco devices, users/administrators must do management on a command line. It is because Cisco has not facilitated its users with a user interface-based configuration. In future research, researchers will try to build a web interface that is used for monitoring and management of the Cisco Router 2800.

\section{CONCLUSION}

Based on the implementation and discussion on "Website-Based Enhanced Interior Gateway Routing Protocol (EIGRP) on a Cisco 2811 Router Utilizing Cisco's Application Programming Interface (Api)," the conclusions are as follows:

1. EIGRP routing can be done web-based using the Cisco API so that there is no need for a command line that requires the ability to control text-based equipment directly.

2. Web-based EIGRP routing for routing management on the Cisco Router 2811 can be done remotely and at short istances u sing the terms of the availability of an internet network and a Web browser on the device used for access.

\section{REFERENCES}

[1] Santoso, K.A., "Konfigurasi dan Analisis Performansi Routing OSPF Pada Jaringan LAN Dengan Simulator Packet Tracer versi 6.2.," In 2016 Jurnal Kajian Teknik Elektro, Vol. 1, No. 1,

[2] A. H. Lubis, E. Julita, and M. Zarlis, "Analisis Routing EIGRP dalam Menentukan Router yang dilalui pada WAN," In Jurnal \& Penelitian Teknik Informatik, Vol. 1, No. 2, April 2017

[3] T. D. Purwanto, "Analisis Kinerja Dynamic Routing pada Protokol Routing EIGRP untuk Menentukan Jalur Terbaik dengan diffusing Update Algorithm (DUAL) (Dynamic Routing Performance Analysis on the EIGRP Routing Protokol to Determine the Best Path Using Diffusing Update Algorithm (DUAL))," In Juita 2018, Vol. VI, No. 2, Nov. 2018

[4] A. Syukur, and L. Julianti, "SIMULASI PEMANFAATAN DYNAMIC ROUTING PROTOCOL EIGRP PADA ROUTER DI JARINGAN UNIVERSITAS ISLAM RIAU BESERTA AUTENTIKASINYA," In JTIIK, Vol. 5, No.1, Maret 2018

[5] A. Ayuningtyas, Sudaryanto, and D. D. Cessara, "SISTEM MANAJEMEN VIRTUAL LOCAL AREA NETWORK (VLAN) PADA CISCO CATALYST 3750 BERBASIS WEB," In 2020 SIMETRIS, vol. 11, no. 1, April 2020

[6] Sudaryanto, "The Effect of Multilayes Switch For Speed Data Transfer On Computer Network," In 2018 Compiler STT Adisutjipto Yogyakarta, Vol. 7, No. 2, Nov. 2018.

[7] Sudaryanto, and D. Nurhayati, "MONITORING INTERFACES FASTETHERNET ON CISCO CATALYST 3750 TO ENSURE USE OF THE SECURITY COMPUTER NETWORK IN STTA COMPUTING LABORATORIES," In 2019 SENATIK, vol. V, Desember 2019

[8] M. Haqqi, and M. Badrul, "SEGMENTASI JARINGAN DENGAN MENGGUNAKAN VIRTUAL LOCAL AREA NETWORK (STUDY KASUS PT. JALUR NUGRAHA EKAKURIR)," In Jurnal Teknik Komputer AMIK BSI, vol. II, No. 2, Agustus 2016

[9] K. A. Santoso, "Konfigurasi dan Analisis Performansi Routing OSPF pada Jaringan LAN dengan Simulator Cisco Packet Tracer versi 6.2," In Jurnal Kajia Teknik Elektro, vol. 1, No. 1, November 2016 
[10] Ponidi, and S. Fitrajaya, "PERANCANGAN SISTEM INFORMASI PENDATAAN PENDUDUK BERBASIS WEB MENGGUNAKAN METODE WATERFALL PADA KECAMATAN GADINGREJO," In Jurnal TAM (Technology Acceptance Model), Vol. 4, Juli 2015 